\title{
GALLIC ACID FROM PODS OF JIRINGA (ARCHIDENDRON JIRINGA [JACK] I.C. NIELSEN) AND ITS ANTIOXIDANT
}

\author{
MISRI YANTY LUBIS ${ }^{1,2 *}$, LAMEK MARPAUNG ${ }^{2}$, MUHAMMAD PANDAPOTAN NASUTION ${ }^{3}$, \\ PARTOMUAN SIMANJUNTAK ${ }^{4,5}$
}

\begin{abstract}
${ }^{1}$ Department of Agrotechnology, Faculty of Agriculture, University of Graha Nusantara, Tor Simarsayang, Padang Sidempuan, Indonesia. ${ }^{2}$ Department of Chemistry, Faculty of Mathematics and Natural Sciences, University of Sumatera Utara, Medan, Indonesia. ${ }^{3}$ Department of Pharmacology, Faculty of Pharmacy, University of North Sumatera, Medan, Indonesia. ${ }^{4}$ Department of Pharmacology, Faculty of Pharmacy, University of Pancasila, Jakarta, Indonesia. ${ }^{5}$ Department of Pharmacology, Research Centre for Biotechnology, Indonesian Institute of
\end{abstract} Science,Cibinong, Indonesia. Email: misriyanty@gmail.com

Received: 06 December 2017, Revised and Accepted: 06 April 2018

ABSTRACT

Objective: This study was aimed to isolate and investigate antioxidant activity of gallic acid in pods of jiringa (Archidendron jiringa [Jack] I.C. Nielsen).

Methods: Pods of jiringa were extracted by maceration. Phenolic compounds were tested using $\mathrm{FeCl}_{3}$. Identification of pure compound was obtained from spectra data from nuclear magnetic resonance of proton $\mathrm{H}\left({ }^{1} \mathrm{H}\right.$ NMR), NMR of carbon $\left({ }^{13} \mathrm{C}\right.$ NMR), infra-red, and mass spectrometry. Antioxidant activity was investigated using 1,1-diphenyl-2-picrylhydrazyl method.

Results: The $\mathrm{IC}_{50}$ of gallic acid from jiringa's pods (A. jiringa [Jack] I.C. Nielsen) was $3.65 \mu \mathrm{g} / \mathrm{ml}$. This value showed that gallic acid from jiringa's pods (A. jiringa [Jack] I.C. Nielsen) had high antioxidant activity.

Conclusions: Gallic acid presents in pods of jiringa (A. jiringa [Jack] I.C. Nielsen) and has high antioxidant activity.

Keywords: Phenolic, Antioxidant, Spectra data, Gallic acid.

(C) 2018 The Authors. Published by Innovare Academic Sciences Pvt Ltd. This is an open access article under the CC BY license (http://creativecommons. org/licenses/by/4. 0/) DOI: http://dx.doi.org/10.22159/ajpcr.2018.v11s1.26582

\section{INTRODUCTION}

Jiringa (Archidendron jiringa [Jack] I.C. Nielsen) is a leguminous tree that is found in Indonesia, Malaysia, and Thailand [1]. It is economically important with diverse uses including as a vegetable (young shoots), food flavoring agent (seeds) [2], medicine (leaves and seeds), and timber for craft work [3]. This plant usually stands up to $25 \mathrm{~m}$ in height with a smooth, grey colored bark. The beans measure up to $3.5 \mathrm{~cm}$ in diameter and $2.0 \mathrm{~cm}$ in thickness. Jiringa's beans are typically taken together with rice as a side dish either as raw vegetable, roasted, fried, or boiled [4,5]. Jiringa is one of the traditional medicine herbs. Seeds have been reported as a source of natural antioxidant [6] that could destroy excess free radicals and prevent oxidative damage [7]. Seeds are used to treat hypertension and diabetic disease; the old leaves burnt to obtain ashes were used against itching [6]. Pods of jiringa until now still much wasted because it is not used, so pile up into garbage.

Currently, to obtain natural antioxidants have grown rapidly because of several degenerative and aging-related diseases [7] such as cancer and cardiovascular diseases. Antioxidants have important role in human health [8]. Antioxidants prevent damage caused by free radical before they attack biological targets in cells $[9,10]$. Synthetic antioxidants may have toxic, carcinogenic, and negative effects to human body [11]. Ascorbic acid (Vitamin C) is one of the sources of natural antioxidants. In recent years, there has been increased interest in the use of natural phenolics as antioxidants due to their safety in nature [11,12]. Ethanolic extract pods of jiringa showed concentration phenolics and potent antioxidant activity [13].

Gallic acid is one of the phenolic compounds widely present in the plant kingdom such as Givotia rottleriformis Griff. [14], Caesalpinia decapetala [15], Elaeagnus angustifolia [16], Terminalia chebula [17], and Crassula ovata (Mill.) [18]. Gallic acid, a naturally occurring lowmolecular-weight triphenolic compound, has been suggested to possess strong antioxidant activity in many studies [7]. Isolation of gallic acid from pods of jiringa (A. jiringa [Jack] I.C. Nielsen) has not been reported.

\section{METHODS}

Plant material

The pods of jiringa (A. jiringa [Jack] I.C. Nielsen) were collected from Namorambe village, Deli Serdang, North Sumatera, Indonesia. Authentication of plant material was carried out at the Herbarium Bogoriensis of the Research Centre for Biology, Indonesian Institute of Sciences (LIPI), Cibinong, Indonesia.

\section{Preparation of extracts}

The pods of jiringa ( $A$. jiringa [Jack] I.C. Nielsen) were dried at room temperature, powdered (4.16 kg) and macerated with methanol. The resultant extracts were then concentrated to dryness in a rotary evaporator. Methanol extract (140 g) was dissolved with water. After filtration, the aqueous solution was partitioned with ethyl acetate solvent. Soluble portion of ethyl acetate solvent was collected ( $37.88 \mathrm{~g}$ ). Further, ethyl acetate extract was partitioned with mixture of $n$-hexanemethanol to get extracts. The methanol extracts were considered as total phenolic (13.87 g). We use $\mathrm{FeCl}_{3}$ to test phenolic compounds.

\section{Separation of compounds}

Total phenolic was subjected to column chromatography silica gel (only $10 \mathrm{~g}$ was subjected) and eluted with chloroform:methanol (chloroform 100\%; 9:1; 8:2; 7:3; $6: 4$; and methanol 100\%) to got six fractions.

\section{Purification}

Fraction IV $(2 \times 200 \mathrm{mg})$ purification by preparative chromatography used eluent $\mathrm{CHCl}_{3}$ :ethyl acetate (6:4) and eluted with methanol:ethyl acetate (1:1) with volume $400 \mathrm{ml}$. From preparative chromatography was got 6 zone and test with $\mathrm{FeCl}_{3}$. Zone $4-5$ cristalizated with acetone and $n$-hexane to got pure compound. 
Table 1: Fraxion's from column chromatography

\begin{tabular}{|c|c|c|c|c|}
\hline No. & Fraction & Number of vial & Mobile phase & Weight (mg) \\
\hline 1. & I & $79-80$ & $\mathrm{CHCl}_{3}: \mathrm{CH}_{3} \mathrm{OH}=9: 1$ & 160 \\
\hline 2. & II & $81-85$ & $\mathrm{CHCl}_{3}^{3}: \mathrm{CH}_{3}^{3} \mathrm{OH}=8: 2$ & 290 \\
\hline 3. & III & $86-111$ & $\mathrm{CHCl}_{3}^{3}: \mathrm{CH}_{3}^{3} \mathrm{OH}=8: 2$ & 4830 \\
\hline 4. & IV & $112-159$ & $\mathrm{CHCl}_{3}^{3}: \mathrm{CH}_{3}^{3} \mathrm{OH}=7: 3$ & 2740 \\
\hline 5. & $\mathrm{~V}$ & $160-198$ & $\mathrm{CHCl}_{3}^{3}: \mathrm{CH}_{3}^{3} \mathrm{OH}=6: 4$ & 440 \\
\hline 6. & VI & $199-408$ & $\mathrm{CH}_{3} \mathrm{OH} 100 \%$ & 830 \\
\hline
\end{tabular}

Table 2: IC $_{50}$ gallic acid from pods of $A$. jiringa (Jack) I.C. Nielsen and ascorbic acid (Vitamin C) as a standard

\begin{tabular}{|c|c|c|c|c|c|c|c|}
\hline Sample & Concentration $(\mu \mathrm{g} / \mathrm{ml})$ & $\mathbf{A 1}^{\mathrm{a}}$ & $\mathbf{A} 2^{\mathbf{b}}$ & $\overline{\mathbf{A}}^{\mathrm{c}}$ & $\mathbf{A}^{\mathrm{d}}$ blank & Inhibition $^{\mathrm{e}}(\%)$ & $\mathrm{IC}_{50}(\mu \mathrm{g} / \mathrm{ml})$ \\
\hline \multirow[t]{5}{*}{ Gallic acid } & 5 & 0.437 & 0.459 & 0.448 & 0.948 & 52.7 & 3.65 \\
\hline & 10 & 0.298 & 0.318 & 0.308 & 0.948 & 67.5 & \\
\hline & 15 & 0.277 & 0.277 & 0.277 & 0.948 & 70.8 & \\
\hline & 20 & 0.103 & 0.107 & 0.105 & 0.948 & 88.9 & \\
\hline & 25 & 0.012 & 0.014 & 0.013 & 0.948 & 98.6 & \\
\hline \multirow[t]{4}{*}{ Ascorbic acid (Vitamin C) } & 5 & 0.437 & 0.492 & 0.464 & 0.948 & 50.98 & 2.31 \\
\hline & 10 & 0.298 & 0.252 & 0.275 & 0.948 & 70.97 & \\
\hline & 20 & 0.103 & 0.201 & 0.151 & 0.948 & 83.99 & \\
\hline & 25 & 0.012 & 0.057 & 0.034 & 0.948 & 96.34 & \\
\hline
\end{tabular}

${ }^{a} \mathrm{~A} 1=$ First absorption measurements of sample, ${ }^{\mathrm{b}} \mathrm{A} 1=$ Second absorption measurements of sample, ${ }^{\mathrm{c}} \overline{\mathrm{A}}=$ Mean absorption measurements of sample,

${ }^{\mathrm{d} A}$ blank=Absorption measurements of blank, ${ }^{\mathrm{e}} \%$ inhibition $=\frac{\mathrm{A} \text { blank }-\overline{\mathrm{A}}}{\mathrm{A} \text { blank }} \times 100 \%$. A. jiringa: Archidendron jiringa

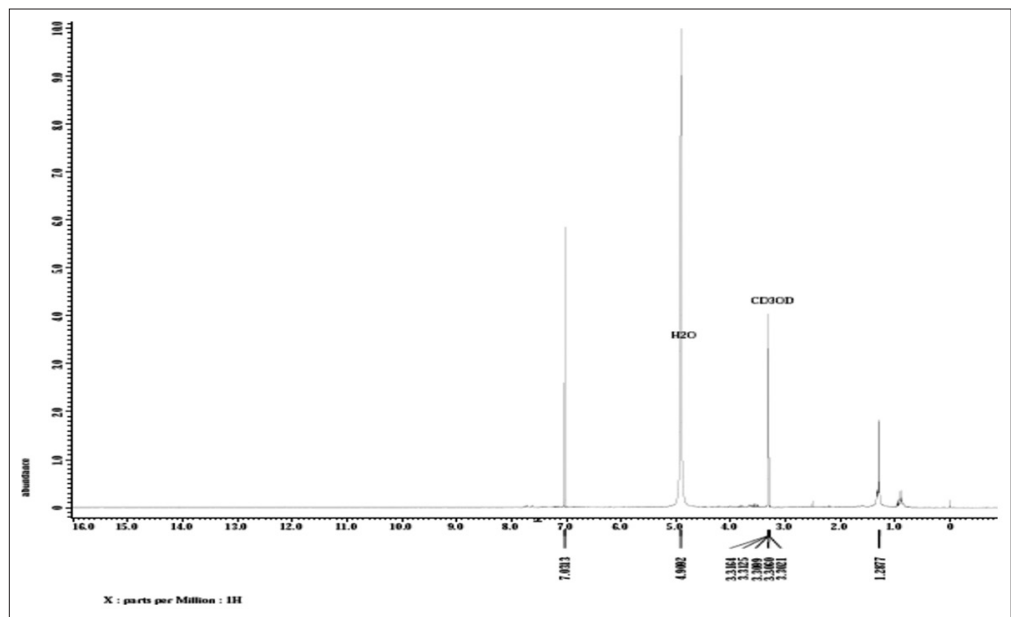

Fig. 1: Data spectra ${ }^{1} \mathrm{H}$ nuclear magnetic resonance Gallic acid from pods of Archidendron jiringa (Jack) I.C. Nielsen

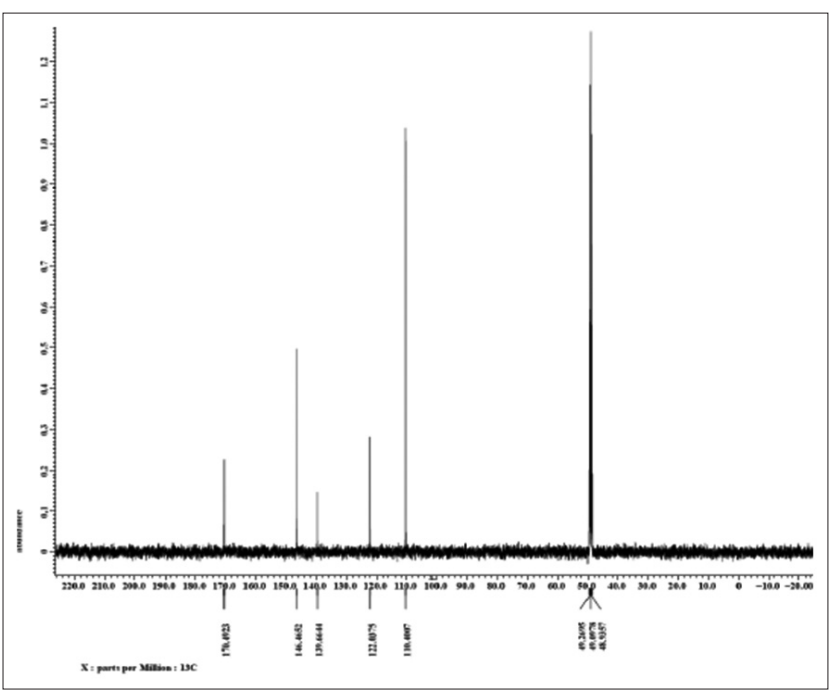

Fig. 2: Data spectra ${ }^{13} \mathrm{C}$ nuclear magnetic resonance Gallic acid from pods of Archidendron jiringa (Jack) I.C. Nielsen
Identification of pure compound

Structure isolated compound was determined by ${ }^{1} \mathrm{H}$ nuclear magnetic resonance (NMR) and ${ }^{13} \mathrm{C}$ NMR on Joel 500 spectrometer $(500 \mathrm{MHz}$ for ${ }^{1} \mathrm{H}$ NMR and $125 \mathrm{MHz}$ for ${ }^{13} \mathrm{C}$ NMR), infrared (IR) spectra (Perkin Elmer Fourier-transform spectrometer Fourier-transform infrared and electron impact mass spectrometry [MS] mass spectra by liquid chromatography [LC]-MS/MS high-performance liquid chromatography Alliance 2659, Waters Detector Photodiode Array 2996).

\section{1,1-Diphenyl-2-picrylhydrazyl (DPPH) method}

Measurement of antioxidants by DPPH method in principle is to measure the occurrence of color fading of DPPH radicals due to the presence of antioxidants that can neutralize free radical molecules. The previously colored DPPH radicals will lose their color if there are antioxidants, because antioxidants will donate their electrons to DPPH radicals, so previously unstable radicals (due to unpaired electrons) become stable (electrons in free radicals are now paired up for donations electron from antioxidants) [19].

\section{RESULTS}

Separation of compounds from column chromatography silica gel (only $10 \mathrm{~g}$ was subjected) and eluted with chloroform: methanol (chloroform 
100\%; 9:1; 8:2; 7:3; 6:4; and methanol 100\%) was gave six fractions shown in Table 1.

From fraction IV after purification by preparative chromatography use eluent $\mathrm{CHCl}_{3}$ :ethyl acetate $(6: 4)$ and eluted with methanol: ethyl acetate (1:1) with volume $400 \mathrm{ml}$ obtained 6 zone. We got pure compound as a gallic acid at zone $4-5$.

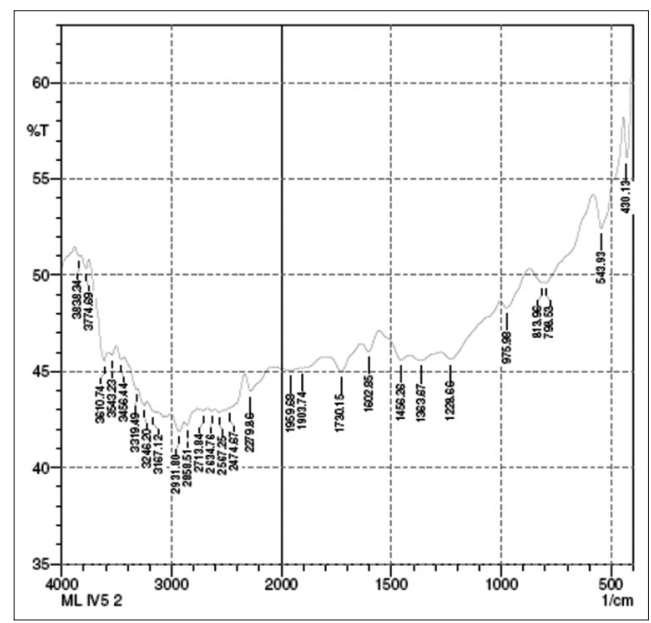

Fig. 3: Spectra data Fourier-transform infrared gallic acid from pods of Archidendron jiringa (Jack) I.C. Nielsen
Structure isolated compound was determined from data ${ }^{1} \mathrm{H}$ NMR, ${ }^{13} \mathrm{C}$ NMR, IR, and MS (Figs. 1-4).

We used DPPH method to evaluated antioxidant activity. The value of $\mathrm{IC}_{50}$ of sample as gallic acid and ascorbic acid as standard calculated from linear regression equation (Figs. 5 and 6).

\section{DISCUSSION}

\section{Phenolic compound test}

Phenolic compound test result indicated phenolic compound. Extract was added $\mathrm{FeCl}_{3}$ showed black-bluish color [21].

\section{Determination chemical structure pure compound}

Pure compound was identified from data ${ }^{1} \mathrm{H}$ NMR, ${ }^{13} \mathrm{C}$ NMR, IR, and LC MS. Data ${ }^{1} \mathrm{H}$ NMR shows peaks at $1.2877 \mathrm{ppm}$ indicated proton $\mathrm{H}$ from acid $\mathrm{OH}$ and 7.0313 indicated proton $\mathrm{H}$ at position number 2 .

Data ${ }^{13} \mathrm{C}$ NMR shows peaks at 170.4923 ppm indicated atom $\mathrm{C}$ at position 7 conjugated to $\mathrm{C}=0 ; 146.4652 \mathrm{ppm}$ indicated atom $\mathrm{C}$ at position 3 and 5; $139.664 \mathrm{ppm}$ indicates atom $\mathrm{C}$ at position 4; $119.87 \mathrm{ppm}$ indicated atom $\mathrm{C}$ at position 1; and $108.14 \mathrm{ppm}$ indicated atom $\mathrm{C}$ at position 2 and 6.

Data IR shows peaks at 3319.49/cm indicated $-\mathrm{COOH} ; 3167.12 / \mathrm{cm}$ indicated C-H; $1730.15 / \mathrm{cm}$ indicated $=\mathrm{C}=0$; and $1602.85 / \mathrm{cm}$ indicated $\mathrm{C}=\mathrm{C}$.

From LC-MS data show m/z 171.02829. Mass of pure gallic acid is 170 . Identification from spectra data above compared with the other reports about isolation of gallic acid [15-18].

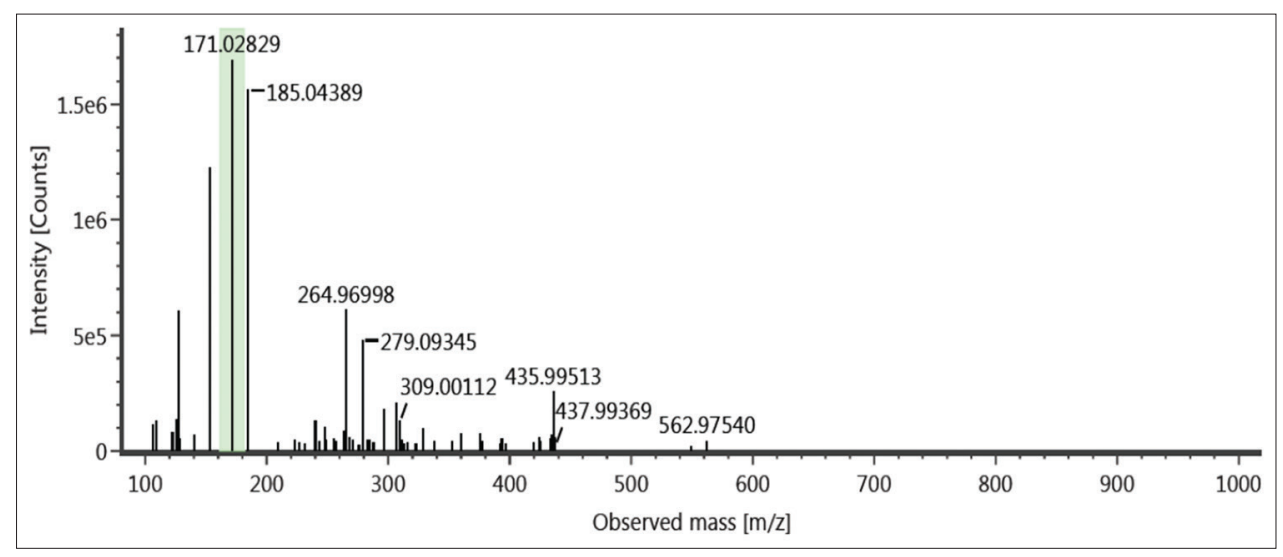

Fig. 4: Spectra data liquid chromatography-mass spectroscopy gallic acid from pods of Archidendron jiringa (Jack) I.C. Nielsen

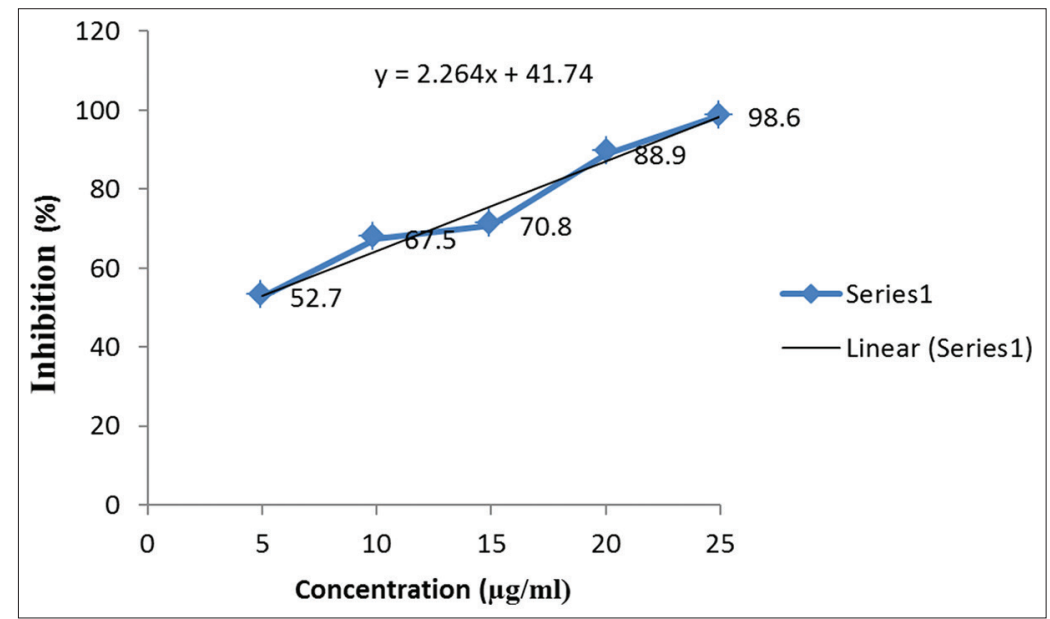

Fig. 5: Chart concentration versus \% inhibition to obtain IC50 of gallic acid 


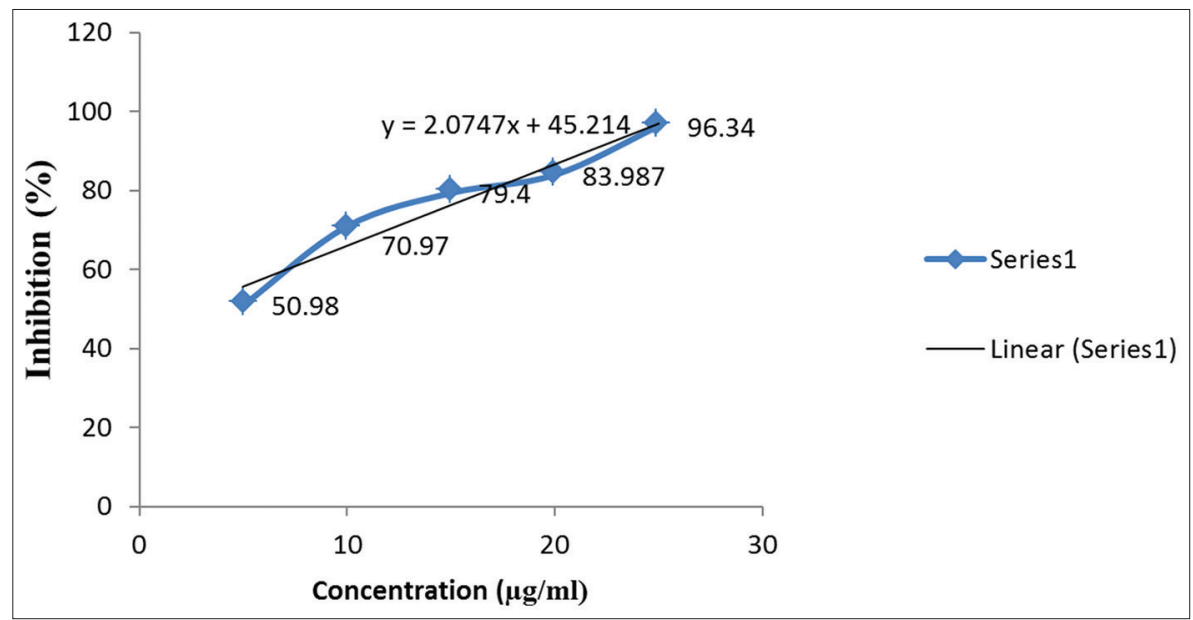

Fig. 6: Chart concentration versus \% inhibition to obtain IC50 of ascorbic acid (Vitamin C) as a standard

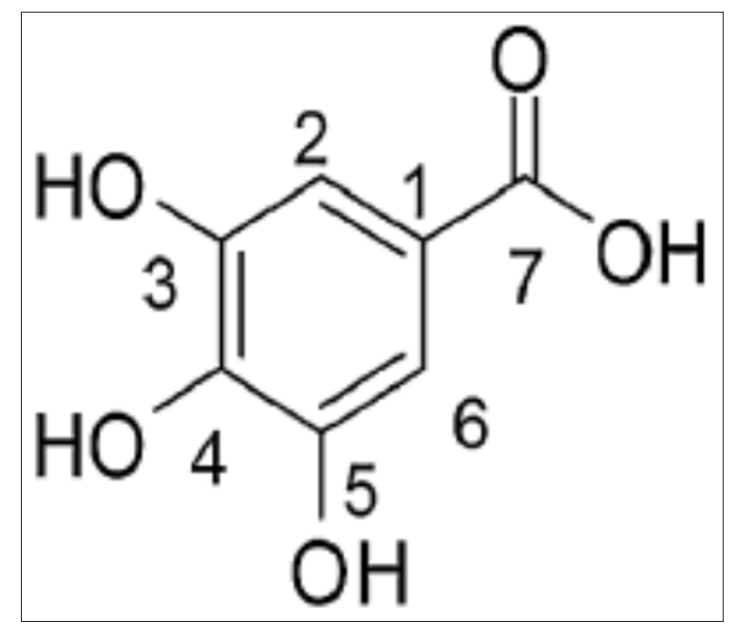

Fig. 7: Chemical structure gallic acid

\section{Antioxidant activity}

The antioxidant activity data were shown in Table 2. We used Vitamin $\mathrm{C}$ (ascorbic acid) as standard. We used linear regression equation from chart in Figs. 5 and 6 to get $\mathrm{IC}_{50}$ value.

\section{CONCLUSION}

Based on ${ }^{1} \mathrm{H}$ NMR, ${ }^{13} \mathrm{C}$ NMR, IR, and MS spectral data, pure compound isolated from A. jiringa (Jack) I.C. Nielsen pods (Fraction 4-5) was determined as gallic acid (Fig. 7), and it has high antioxidant activity which can be used for preventing or treating oxidative disease.

\section{ACKNOWLEDGMENT}

We thank to Herbarium Bogoriensis of the Research Centre for Biology, Indonesian Institute of Sciences (LIPI), Cibinong, Indonesia, for the botanical identification of jiringa's plant that used in this research.

\section{REFERENCES}

1. Lim TK. Edible Medicinal and Non-Medicinal Plants. Vol. 2. Heidelberg, London, New York: Fruits, Springer Dordrecht; 2012. p. 544-8.

2. Ashuwini S, Karim AA, Rajeev B. Pithecellobium jiringalegume flour for potential food applications: Studieson their physico-chemical and functional properties. Food Chem 2012;130:528-35.

3. Charungchitrak S, Petsom A, Sangvanich P, Karnchanatat A. Antifungal and antibacterial activities of lectin from the seeds of Archidendron jiringa nielsen. Food Chem 2011;126:1025-32.

4. Muslim N, Abdul MA. Pithecellobium jiringa: A Traditional Medicinal
Herb. WebmedCentral Complementary Medicine (WMC001371); 2010;1:1-4

5. Ruzilawati AB, Ahmad I, Sulaiman SF. Effect of Pithecellobium jiringa as antimicrobial agent. Bangladesh J Pharmacol 2012;7:131-4.

6. Mohammad AC, Nik NN, Wahyu B, Mohd OA. Supercritical Carbon Dioxide Extraction of Constituents of Pithecellobium jiringa Seeds and their Identification using Time of Flight Gas Spectrometry. Proceedings of the $1^{\text {st }}$ International Conference on Natural Resources Engineering \& Technology 24-25 th July 2006. Putrajaya, Malaysia 2006. p. 616-25.

7. Bharti B, Neha S, Rita K. Gallic acid: A versatile antioxidant with promising therapeutic and industrial applications. Royal Soc Chem 2015;5:27540-57.

8. Khoddami A, Meredith A, Thomas W. Techniques for analysis of plant phenolic compounds. J Mol 2013;18:2328-75.

9. Matkowski A. Plant in vitro culture for the production of antioxidants. A review. Biotechnol Adv 2008;26:48-560.

10. Mileo AM, Stefania M. Polyphenols as modulator of oxidative stress in cancer desease: New therapeutic strategies. Oxid Med Cell Longev. 2016;2016:6475624

11. Baydar NG, Ozkanb G, Yasar S. Evaluation of the antiradical and antioxidant potential of grape extracts. Food Control 2007;18:1131-36.

12. Andreata RH. New species of smilax and a key to all species from minas gerais, Brazil. Syst Bot 2009;34:28-31.

13. Muslim NS, Nassar ZD, Abdalrahim FA, Shafaei A, Idris N, Majid AM, et al. Antiangiogenesis and antioxidant activity of ethanol extracts of Pithecellobium jiringa. BMC Complementary Altern Med 2012;12:210:20

14. Kamatham S, Kumar N, Gudipalli P. Isolation and characterization of gallic acid and methyl gallate from the seed coats of Givotia rottleriformis Griff. and their anti-proliferative effect on human epidermoid carcinoma A431 cells. Toxicol Report 2015;2:520-9.

15. Bhadoriya U, Sharma P, Solanki SS. In vitro free radical scavenging activity of gallic acid isolated from Caesalpinia decapetale wood. Asian Pac J Trop Desease 2012;???:S833-6.

16. Abri A, Maleki M. Isolation and identification of gallic acid from the Eleagnus angustifolia leaves and determination of total phenolic, flavonoids contents and investigation of antioxidant activity. Iran Chem Comunication 2015;4:146-54.

17. Sri G, Rachael RD, Shenbagaradhai R. Isolation, identification and characterization of gallic acid from leaves of Terminalia chebula (Retz). Int J Green and Herb Chem 2015;4:78-91.

18. Nantenaina T, Zoarilala RR, David R, Reine D, Ramilison R, Eric M, et al. Isolation of the gallic acid in the butanolic fraction of Crassula ovata (Mill.) druce (Crasullaceae) leaves and its vaso-relaxing effect. Am J Innov Res Appl Sci 2017;10:200-7.

19. Musa KH, Abdullah A, Al-Haiqi. Determination of DPPH free radical scavenging activity: Aplication of artificial neural networks. Food Chemistry 2016;194:705-11.

20. Lubis MY, Siburian R, Marpaung L, Simanjuntak P, Nasution MP. Methyl gallate from jiringa (Archidendron jiringa) and antioxidant activity. Asian J Pharm Clin Res 2018;11:346-50.

21. Tiwari P, Kumar B, Kaur M, Kaur G, Kaur H. Phytochemical screening and extraction: A review. Int Pharm Sci 2011;1:98-106. 